\title{
Distribution of Phenolic Components and Their Antioxidant Capacity in Strawberries
}

\author{
Ying Wang ${ }^{1}$, Marie Thérèse Charles ${ }^{2}$, Wen-xuan Dong ${ }^{3}$, Claudine Dubé $^{2} \&$ Shahrokh Khanizadeh $^{2,4}$ \\ ${ }^{1}$ College of Horticulture, Jilin Agricultural University, Changchun, Jilin Province, China \\ ${ }^{2}$ Horticulture Research and Development Centre, Agriculture and Agri-Food Canada, Quebec, Canada \\ ${ }^{3}$ College of Horticulture, Shenyang Agricultural University, Shenyang, Liaoning Province, China \\ ${ }^{4}$ Eastern Cereals and Oilseed Research Centre, Agriculture and Agri-Food Canada, Canada
}

Correspondence: Shahrokh Khanizadeh, Eastern Cereals and Oilseed Research Centre, Agriculture and Agri-Food Canada, Ottawa, Ontario, Canada. Tel: 1-613-759-6563. E-mail: shahrokh.khanizadeh@agr.gc.ca web http://khanizadeh.info

Received: September 6, 2013 Accepted: February 5, 2014 Online Published: February 12, 2014

doi:10.5539/jfr.v3n2p54

URL: http://dx.doi.org/10.5539/jfr.v3n2p54

\begin{abstract}
Total phenolic content, phenolic composition, and total antioxidant capacity of neck and bottom parts of two strawberry cultivars, 'Chambly' and 'LL0220-10', were evaluated using the Folin-Ciocalteu method, high performance liquid chromatography, and ferric reducing/antioxidant power, respectively. A significant interaction $(p<0.05)$ was observed between examined parts and cultivars. The highest content of phenolics was detected in the bottom part of 'Chambly' when compared to its neck, while there was no difference between neck and bottom of 'LL0220-10'. The most evident group was the anthocyanins accounting for $83.53 \%$ of the total phenolic content. These data are a step in establishing a correlation between fruit anatomy and its chemical composition, which could be useful in breeding new strawberry cultivars more resistant to diseases.
\end{abstract}

Keywords: strawberry, fruit parts, Botrytis cinerea, phenolic content, phenolic composition, antioxidant activity, disease resistance

\section{Introduction}

Strawberry (Fragaria $\times$ ananassa Duch.) is widely cultivated and very important crop in Canada. It is very delicate and perishable which makes it very susceptible to grey mold by Botrytis cinerea, reducing much its postharvest life. It is really difficult to control grey mold because that pathogen can infect all plant parts, mostly during the ripening process and at harvest, when the use of fungicide is not possible, which results in a shorter shelf life (Martínez-Romero et al., 2007). Thus, grey mold is the number one destructive disease for strawberry, all around the world (Sutton, 1998). There are many cultural practices which can prevent its growth, including fungicide applications, temperature and atmosphere control, better irrigation and wetness, at different growth stages and postharvest, but the best method still is the selection of cultivars with a greater resistance to its damaging effects (Hébert et al., 2002; Terry, Joyce, Adikaram, \& Khambay, 2004). In view of results obtained through many experiments, researchers have attributed variations in the inherent natural disease resistance of strawberry to its skin strength (Gooding, 1976), firmness (Barritt, 1980), flower susceptibility (Bristow, Campbell, Papendick, \& Elliot, 1986), raised neck, and reflexed calyx. Firm flesh strawberry seems to be more resistant to grey mold (Olcott-Reid \& Moore, 1995) which is also associated to specific phenolics and total antioxidant capacity (TAC). Cultivars having different phenolic contents also have different shelf life and susceptibilities to the pathogen infection. For instance, the June-bearing genotype 'La Clé des Champs' has a higher total phenolic content (TPC) and lower susceptibility to postharvest disease compared with 'FIN0132-11', a day-neutral genotype (Khanizadeh, Ehsani-Moghaddam, \& Levasseur, 2006). Phenolic compounds such as catechin, which is the main component of proanthocyanidins, are oligomers of flavan-3-ols found in unriped, green-coloured strawberries, and are related to B. cinerea resistance (Jersch, Scherer, Huth, \& Schlösser, 1989; Feucht, Treutter, \& Christ, 1992; Di Venere et al., 1998).

The main objectives of our work were to establish whether phenolic composition between fruit parts differed, and if so, to investigate its effect on disease susceptibility by grey mold. 


\section{Materials and Method}

\subsection{Chemicals}

Ellagic, gallic, and $p$-coumaric acids, sodium carbonate $\left(\mathrm{Na}_{2} \mathrm{CO}_{3}\right)$, and Folin-Ciocalteu reagent were purchased from Sigma Chemical Co. (St. Louis, Missouri, USA), quercetin-3-galactoside from Fluka Chemie GmbH (Buchs, Switzerland), cyanidin-3-galactoside from Indofine Chemical Co. (Hillsborough, New Jersey, USA), and all other solvents from Caledon Laboratories Ltd. (Georgetown, Ontario, Canada).

\subsection{Sample Preparation and Extraction Procedures}

Strawberry cultivars, 'Chambly' and 'LL0220-10', which have raised neck, elevated calyces and intense red fruits with uniform and deep coloured flesh, were used in a complete randomized design using four replicates. According to previous evaluations, 'LL0220-10' is more resistant to B. cinerea than 'Chambly'. During the 2006-2007 harvesting seasons, fruits were picked randomly at commercial maturity, at the Agriculture and Agri-Food Canada experimental farm located in L'Acadie, Quebec, Canada (longitude $73^{\circ} 35^{\prime} \mathrm{W}$, latitude $45^{\circ} 32^{\prime}$ $\mathrm{N}$ ). The harvested fruits were separated into neck and bottom parts (Figure 1), and 3-150 g lots from each part were weighed. Whole fruits samples were also used for comparison.

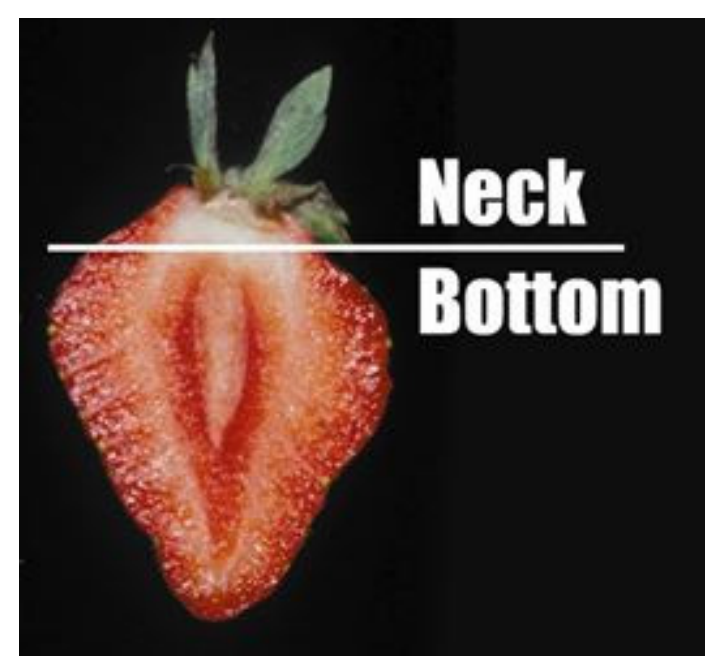

Figure 1 . Strawberry parts used for analysis

All samples were cut into small pieces and frozen immediately into liquid nitrogen before being stored at $-80{ }^{\circ} \mathrm{C}$ for future analysis.

From each fruit lot, 10 samples were pooled and ground in a mortar containing liquid nitrogen. These frozen samples were then mixed with $50 \mathrm{~mL}$ of $50 \%$ methanol with a Polytron blender (Brinkmann Instruments, New York, USA). The mixture obtained was passed through Whatman No. 1 filter paper and thereafter through a 0.45 $\mu \mathrm{m}$ Acrodisc syringe filter (Gelman Laboratory, Michigan, USA). The final filtrate was kept at $-20{ }^{\circ} \mathrm{C}$ until analysis.

\subsection{Total Phenolic Content, Phenolic Composition and Total Antioxidant Capacity}

TPC was determined by the Folin-Ciocalteu method (Slinkard \& Singleton, 1977), with slight modifications (Wang et al., 2012). Phenolic composition (PC) was analyzed by HPLC (Wang et al., 2012) and TAC was estimated by the use of the ferric reducing/antioxidant power (FRAP) (Benzie \& Strain, 1996) with modifications for the 96-well microplate reader.

\subsection{Sensory and Physical Evaluations}

For each cultivar, five fruits were placed on top of a filter paper previously placed in a petri dish, at room temperature. Fruit weight, juice loss, glossiness and postharvest diseases were evaluated daily, until fruits were no more marketable.

Fruit firmness was assessed by use of a LRX tester (Lloyd Instruments, Brampton ON. Canada). A constant $50 \mathrm{~N}$ weight with a load cell sensitivity of $100.4 \%$ was applied, with a probe $3.5 \mathrm{~cm}$ in diameter. 
Five whole fruits or fruit parts were taken, at random, to determine the soluble solids content (SSC) and titratable acidity (TA). Juice extracts were obtained by use of a Supreme Juicerator juicer (ACME Juicer Mfg. Co., New Hartford, Connecticut, USA). SSC was determined at room temperature by means of a refractometer (ABBE MARK II; Reichert-Jung, Markham, Ont., Canada). TA was determined by mixing $9 \mathrm{~mL}$ distilled water with 1 $\mathrm{mL}$ of the strawberry juice. The mixture obtained was then titrated by means of a $\mathrm{pH}$ meter (Accumet AB15 Basic pH meter; Fisher Scientific, Ont., Canada), using 0.1 N NaOH until pH 8.1.

\subsection{Statistical Analysis}

Data were analyzed by use of the ANOVA and GLM procedures of SAS (SAS Institute, 1989), where means were separated by the least significant difference (LSD), at the 0.05 level.

\section{Results}

Results obtained for TPC and TAC are presented in Table 1.

Table 1. Distribution of total phenolic content and total antioxidant capacity of the different fruit parts of the two selected strawberry lines

\begin{tabular}{|c|c|c|c|c|c|c|c|c|}
\hline Cultivar \& parts & $\begin{array}{l}\text { Total phenolic } \\
\text { content }^{\mathrm{a}} \\
\left(\mu \mathrm{g} \text { GAE g }{ }^{-1}\right)\end{array}$ & $\begin{array}{c}\text { Total } \\
\text { antioxidant } \\
\text { capacity }^{\mathrm{b}} \\
\left(\mu \mathrm{g} \mathrm{AAE} \mathrm{g}^{-1}\right)\end{array}$ & $\begin{array}{c}\text { Weight } \\
\text { (g) }\end{array}$ & $\begin{array}{l}\text { Soluble } \\
\text { solids } \\
\text { content } \\
\left({ }^{\circ} \text { Brix) }\right.\end{array}$ & $\begin{array}{l}\text { Titratable } \\
\text { acidity }\end{array}$ & Firmness & $\mathrm{pH}$ & $\begin{array}{l}\text { Shelf-life at } \\
\text { room } \\
\text { temperature } \\
\text { (d) }\end{array}$ \\
\hline $\begin{array}{c}\text { 'Chambly' } \\
\text { Neck }\end{array}$ & $774.87 \mathrm{bc}$ & $1178.00 \mathrm{a}$ & $17.57 b$ & $6.52 b c$ & $0.79 \mathrm{a}$ & - & $3.90 \mathrm{a}$ & - \\
\hline $\begin{array}{l}\text { 'Chambly' } \\
\text { Bottom }\end{array}$ & $1093.11 \mathrm{a}$ & $1350.30 \mathrm{a}$ & $51.03 \mathrm{a}$ & $6.73 \mathrm{abc}$ & $0.54 b$ & - & $3.60 \mathrm{~b}$ & - \\
\hline $\begin{array}{l}\text { 'Chambly' } \\
\text { Whole fruit }\end{array}$ & $893.34 \mathrm{ab}$ & $1022.00 \mathrm{a}$ & $55.55 \mathrm{a}$ & $7.36 \mathrm{ab}$ & $0.78 \mathrm{a}$ & $7.5 \mathrm{a}$ & $4.00 \mathrm{a}$ & 2 \\
\hline $\begin{array}{r}\text { 'LL0220-10' } \\
\text { Neck }\end{array}$ & $585.09 \mathrm{~cd}$ & $1247.00 \mathrm{a}$ & $16.34 b$ & $6.27 \mathrm{c}$ & $0.80 \mathrm{a}$ & - & $3.67 \mathrm{~b}$ & - \\
\hline $\begin{array}{c}\text { 'LL0220-10' } \\
\text { Bottom }\end{array}$ & $459.85 \mathrm{~d}$ & $1259.70 \mathrm{a}$ & $54.57 \mathrm{a}$ & $6.93 \mathrm{abc}$ & $0.44 b c$ & - & $3.59 b$ & - \\
\hline $\begin{array}{l}\text { 'LL0220-10' } \\
\text { Whole fruit }\end{array}$ & $903.10 \mathrm{ab}$ & $1449.30 \mathrm{a}$ & $57.24 \mathrm{a}$ & $7.47 \mathrm{a}$ & $0.89 \mathrm{a}$ & $9.6 \mathrm{~b}$ & $3.81 \mathrm{ab}$ & 3 \\
\hline Mean & 784.89 & 1265.67 & 42.05 & 6.88 & 0.58 & 10.0 & 3.76 & - \\
\hline $\mathrm{LSD}_{0.05}{ }^{\mathrm{c}}$ & 280.53 & 588.24 & 8.42 & 0.84 & 0.10 & 1.50 & 0.13 & - \\
\hline
\end{tabular}

The Folin-Ciocalteu and ferric reducing/antioxidant power (FRAP) analyses were performed in triplicate.

${ }^{a}$ Total phenolic content (Folin-Ciocalteu analysis) is expressed as micrograms of gallic acid equivalent (GAE) per gram fresh-frozen weight.

${ }^{\mathrm{b}}$ Antioxidant capacity (FRAP assay) is expressed as micrograms of ascorbic acid equivalent (AAE) per gram fresh-frozen weight.

${ }^{c} \operatorname{LSD}_{0.05}$ : Least significant difference at the 0.05 level.

We obtained significant variations among the fruit parts of the two cultivars, 'Chambly' and 'LL0220-10'. TPC values varied from 459.85 - $1093.11 \mu \mathrm{g}$ gallic acid eq. (GAE) $\mathrm{g}^{-1}$. Bottom part of 'Chambly' contained higher TPC than its neck (1093.11 and $774.87 \mu \mathrm{g} \mathrm{GAE} \mathrm{g}^{-1}$, respectively). When compared to 'Chambly', both neck and bottom parts of 'LL0220-10' had lower TPC, and there were no significant differences in between them (585.09 and $459.85 \mu \mathrm{g} \mathrm{GAE} \mathrm{g}^{-1}$, respectively). Even though TPC of the samples were different, there were no significant differences between TAC values obtained (Table 1).

PC was separated into 5 components. Among those, anthocyanins were the most predominant one (83.53\%), 
followed by flavonols (7.89\%) and hydroxycinnamic, benzoic and ellagic acids (3.66, 2.71 and 2.22\%, respectively. (Table 2)

Table 2. Phenolic composition ( $\mu \mathrm{g} \mathrm{g}^{-1}$ fresh-frozen weight) of the different fruit parts of the two selected strawberry lines

\begin{tabular}{lllllll}
\hline \multicolumn{1}{c}{ Cultivar and part } & $\begin{array}{c}\text { Total } \\
\text { anthocyanins } \\
(520 \mathrm{~nm})\end{array}$ & $\begin{array}{c}\text { Total } \\
\text { hydroxycinna } \\
\text { mic acids } \\
(320 \mathrm{~nm})\end{array}$ & $\begin{array}{c}\text { Total } \\
\text { flavonols } \\
(360 \mathrm{~nm})\end{array}$ & $\begin{array}{c}\text { Total } \\
\text { ellagic } \\
\text { acids } \\
(254 \\
\mathrm{nm})\end{array}$ & $\begin{array}{c}\text { Total } \\
\text { benzoic } \\
\text { acids } \\
(280 \mathrm{~nm})\end{array}$ & $\begin{array}{c}\text { Total } \\
\text { phenolics } \\
\text { (sum of } \\
\text { five } \\
\text { groups) }\end{array}$ \\
\hline 'Chambly', neck & $751.78 \mathrm{ab}$ & $33.22 \mathrm{~b}$ & $85.39 \mathrm{a}$ & $12.66 \mathrm{ab}$ & $18.84 \mathrm{bc}$ & $901.88 \mathrm{~b}$ \\
'Chambly', bottom & $869.33 \mathrm{a}$ & $60.70 \mathrm{a}$ & $86.32 \mathrm{a}$ & $17.05 \mathrm{ab}$ & $46.06 \mathrm{a}$ & $1079.45 \mathrm{a}$ \\
'Chambly', whole fruit & $695.00 \mathrm{~b}$ & $40.21 \mathrm{~b}$ & $56.50 \mathrm{~b}$ & $18.23 \mathrm{a}$ & $23.16 \mathrm{~b}$ & $833.09 \mathrm{~b}$ \\
'LL0220-10', neck & $464.00 \mathrm{c}$ & $8.09 \mathrm{c}$ & $31.76 \mathrm{c}$ & $17.55 \mathrm{a}$ & $13.62 \mathrm{bcd}$ & $535.02 \mathrm{c}$ \\
'LL0220-10', bottom & $435.99 \mathrm{c}$ & $12.80 \mathrm{c}$ & $26.78 \mathrm{c}$ & $12.09 \mathrm{~b}$ & $9.48 \mathrm{~cd}$ & $497.15 \mathrm{c}$ \\
'LL0220-10', whole & $395.44 \mathrm{c}$ & $3.42 \mathrm{c}$ & $53.73 \mathrm{~b}$ & $18.55 \mathrm{a}$ & $6.13 \mathrm{~d}$ & $477.27 \mathrm{c}$ \\
fruit & 601.92 & 26.41 & 56.86 & 16.02 & 19.55 & 720.65 \\
Mean $_{\text {LSD }}{ }^{\mathrm{b}}$ & 129.10 & 11.09 & 18.30 & 6.06 & 10.37 & 154.83 \\
\% Total & 83.53 & 3.66 & 7.89 & 2.22 & 2.71 & 100.00 \\
\hline
\end{tabular}

Data are the average of triplicates.

a Phenolic groups were quantified as follows: ellagic acids as ellagic acid, anthocyanins as cyanidin-3-galactoside, hydroxycinnamic acids as $p$-coumaric acid, flavonols as quercetin-3-galactoside, and benzoic acids as gallic acid.

${ }^{\mathrm{b}} \mathrm{LSD}_{0.05}$ : Least significant difference at the 0.05 level.

The bottom and neck parts of 'Chambly' contained the highest level of anthocyanins (869.33 and $751.78 \mu \mathrm{g} \mathrm{g}^{-1}$, respectively), while the neck and bottom parts of 'LL0220-10' had the lowest (464.00 and $435.99 \mu \mathrm{g} \mathrm{g}^{-1}$, respectively). There were no significant differences between the parts of 'LL0220-10'.

The bottom and neck parts of 'Chambly' had the biggest concentration of flavonols (86.32 and $85.39 \mu \mathrm{g} \mathrm{g}^{-1}$, respectively) when compared with 'LL0220-10' (26.78 and $31.76 \mu \mathrm{g} \mathrm{g}^{-1}$, respectively). There were no significant differences between bottom and neck parts of each cultivar.

Bottom part of 'Chambly' contained the highest levels of hydroxycinnamic and benzoic acids (60.70 and 46.06 $\mu \mathrm{g} \mathrm{g}^{-1}$, respectively), which were significantly different from the levels in its neck. No significant differences were found between the bottom and neck parts of 'LL0220-10'. Ellagic acids were significantly higher in the neck of 'LL0220-10' compared to its bottom, but there was no significant differences observed between neck and bottom of 'Chambly'.

The total phenolics of the five groups were obtained by HPLC and ranged from 477.27-1079.45 $\mu \mathrm{g} \mathrm{g}^{-1}$. The highest total of phenolics was found in the bottom and neck parts of 'Chambly' $\left(1079.45 \mu \mathrm{g} \mathrm{g}^{-1}\right.$ and $901.88 \mu \mathrm{g}$ $\mathrm{g}^{-1}$, respectively). There were no significant differences between the neck and the bottom parts of 'LL0220-10'.

The two strawberry cultivars differed in firmness, which was determined instrumentally (Table 1). Compared with 'Chambly', 'LL0220-10' was firmer and had a better shelf life, 3 versus 2 days.

The diversity of the chemical components confers the flavour, taste and aroma, to the strawberry. Good flavour is mainly obtained when high sugar and, especially, acid contents are at their optimum, (Kader 1991). In our experiment, SSC and TA varied, depending on strawberry part (Table 1). The whole fruit of 'LL0220-10' had the highest SSC, the whole fruit of 'Chambly' had the second highest SSC, and the lowest SSC was in the neck of 'LL0220-10'. The TA was the highest in the whole fruit of 'LL0220-10' and lowest in its bottom part. The highest $\mathrm{pH}$ values were found in the whole fruit and neck of 'Chambly' (4.00 and 3.90, respectively). 


\section{Discussion}

Grey mold development is one of the principal causes of diseases at postharvest, which contributes mainly to shorter shelf life of strawberries. Strawberry petals are an important inoculum source of grey mold during flowering and fruit development (Boff, Kraker, Gerlagh, \& Kohl, 2003). Infection remains underlying until fruits maturity and development is abundant which results in fruit rotening with much sporulation of the pathogen involved, Botrytis cinerea (Kovach, Petzoldt, \& Harman, 2000). This pathogen is also responsible of significant losses at shipping, and for marketable fruits (Ceponis, Cappellini, \& Lightner, 1987). Besides fungicides, many biological controlling agents may be effective in reducing disease caused by grey mold on strawberries (Guinebretiere, Nguyen-The, Morrison, Reich, \& Nicot, 2000). However, these methods have some disadvantages for fruit yield or quality, and thus selecting and breeding resistant cultivars is the primary action for fruit producers.

Strawberry is a good source of natural antioxidants whose extracts exhibit high enzymatic activity against free radicals and for oxygen detoxification (Wang, Feng, Lu, Bowman, \& Ding, 2005). Numerous studies have concluded that the antioxidant properties of constitutive and induced phenolic compounds provide good defence plant tissue against pathogen intrusions (Nicholson \& Hammerschmidt, 1992; Prusky, 1996). Hébert, Gauthier and Gosselin (2001), and Hébert et al. (2002) used a similar method to that of Jersch et al. (1989) to find out that aqueous extracts of the unriped fruit of 'Chandler' had an unequivocal antifungal action against $B$. cinerea mycelial growth and conidial germination. In strawberry cultivars, the main phenolic components having antioxidant properties are: ellagic and gallic acids, anthocyanins (cyanidin-3-glucoside, pelargonidin-3-glucoside), catechin, and flavonols (quercetin-3-galactoside) which confers a better resistance to B. cinerea. A drop in strawberry disease resistance is associated with a reduction of specific proanthocyanins having antifungal activity during the development of the fruit, and the greatest antifungal activity is found in achenes at the green stage I of the fruits extracts, especially in achenes (Terry et al., 2004).

In this research, the highest total of phenolics was found in the bottom part of 'Chambly' in relation to its neck, whereas for 'LL0220-10' there were no obvious differences. Anthocyanins are the predominant group of unique phenolics in the anthocyanidins group responsible for the red colour of the strawberry flesh (Wang, Zheng, \& Galletta, 2002). However, in the present work, we did not find correlations between individual PC and TAC, similar conclusion to that of Meyers, Watkins, Pritts and Liu, (2003). In previous studies, it was noted that there is positive or negative between free phenolics and TAC, in many kinds of fruits (Kalt et al., 2003; Rekika et al., 2005; Xie et al. 2013). Macheix, Fleuriet and Billot (1990) reported that strawberries contain plenty of different phenolic compounds, which differ depending on the cultivar. Furthermore, it has been noted that relative proportions and differences of PC, within the profiles, could afterwards produce multiple diversities in antioxidant activity (AA) or other bioactivities.

Ellagic acid has a negative impact on mycelial growth and germ tube elongation at low concentration (36 ppm), whereas it promotes them when high (Tao et al., 2010). Hébert et al. (2002) reported a better resistance level to grey mold growth using extracts of 6 strawberry cultivars, but it did not mention which were the phenolic compounds or mixes responsible for the inhibition of B. cinerea growth. As for conclusions by Tao et al. (2010), in this exercise, we found that there is a negative correlation between shelf life and phenolic compounds (data not shown). Strawberry flavour derives from tastes and aromas of many chemical components which interact together. High sugar and relative high acid content is required for good flavour (Kader, 1991). In this present study, even though 'LL0220-10' was firmer and had a shelf life that was $1 \mathrm{~d}$ longer compared with 'Chambly', the SSC and TA of the whole fruits of the two cultivars were similar.

In terms of anatomy, strawberry fruits with a raised neck and a reflexed calyx do not retain much water and have increased air circulation, features that may reduce infection by the pathogen. Literature reports that although strawberry fruits contain only $1 \%$ achenes based on fresh-weight, they contribute mostly to the AA and total phenolics ( $14 \%$ and $11 \%$, respectively), and compared to immature ones, matured achenes contain more phenolics and have greater AA (Aaby, Skrede, \& Wrolstad, 2005). In our study, the TAC of the bottom part of 'Chambly' was significantly higher in relation to its neck, which difference may be because of its higher achene content in that part.

In summary, the TPC and AA of strawberry may be due mainly to its genetic but also to their characteristical morphology and anatomy, which could also be in relation to its susceptibility to grey mold. Further investigation is then required for a better understanding.

\section{References}

Aaby, K., Skrede, G., \& Wrolstad, R. E. (2005). Phenolic composition and antioxidant activities in flesh and 
achenes of strawberries (Fragaria ananassa). Journal of Agricultural Food Chemistry, 53, 4032-4040. http://dx.doi.org/10.1021/jf048001o

Barritt, B. H. (1980). Resistance of strawberry clones to Botrytis fruit rot. Journal of the American Society for Horticultural Science, 105, 160-164.

Benzie, I. F. F., \& Strain, J. J. (1996). The ferric reducing ability of plasma (FRAP) as a measure of "antioxidant power": The FRAP assay. Analytical Biochemistry, 239, 70-76. http://dx.doi.org/10.1006/abio.1996.0292

Boff, P., de Kraker, J., Gerlagh, M., \& Köhl, J. (2003). The role of petals in development of grey mould in strawberries. Fitopatologia Brasileira, 28, 76-83. http://dx.doi.org/10.1590/S0100-41582003000100011

Bristow, K. L., Campbell, G. S., Papendick, R. I., \& Elliot, L. F. (1986). Simulation of heat and moisture transfer through a surface residue-soil system. Agricultural and Forest Meteorology, 36, 193-214. http://dx.doi.org/10.1016/0168-1923(86)90035-3

Ceponis, M. J., Cappellini, R. A. \& Lightner, G. W. (1987). Disorders in sweet cherry and strawberry shipments to the New York market, 1972-1984. Plant Disease, 71, 472-475.

Di Venere, D., Linsalata, V., Ippolito, A., Nigro, F., Arcuti, P., \& Lattanzio, V. (1998). Endogenous phenolics, ripening and susceptibility of strawberry fruits (Fragaria $\times$ ananassa Duch.) to post-harvest diseases. In F. Charbonnier, J. M. Delacotte \& C. Rolando (Eds.), Polyphenols Communication, 98, (Vol. 2, pp. 459-460). Bordeaux, France: Groupe Polyphenols.

Feucht, W., Treutter, D., \& Christ, E. (1992). The precise localization of catechins and proanthocyanidins in protective layers around fungal infections. Journal of Plant Diseases and Protection, 99, 404-413.

Gooding, H. J. (1976). Resistance to mechanical injury and assessment of shelf life in fruits of strawberry Fragaria $\times$ ananassa. Horticultural Research, 16, 71-82.

Guinebretiere, M. H., Nguyen-The, C., Morrison, N., Reich, M., \& Nicot, P. (2000). Isolation and characterization of antagonists for the biocontrol of the postharvest wound pathogen Botrytis cinerea on strawberry fruits. Journal of Food Protection, 63, 386-394.

Hébert, C., Charles, M. T., Gauthier, L., Willemot, C., Khanizadeh, S., \& Cousineau, J. (2002). Strawberry proanthocyanidins: biochemical markers for Botrytis cinerea resistance and shelf-life predictability. Acta Horticulturae, 567, 659-662.

Hébert, C., Gauthier, L., \& Gosselin, A. (2001). Identification of strawberry proanthocyanins as antagonists to Botrytis cinerea. In Proceedings of the 98th Annual International Conference of the American Society for Horticultural Science. 22-25 June, Sacramento, California, USA.

Jersch, S., Scherer, C., Huth, G., \& Schlösser, E. (1989). Proanthocyanidins as basis for quiescence of Botrytis cinerea in immature strawberry fruits. Journal of Plant Diseases and Protection, 96, 365-378.

Kader, A. A. (1991). Quality and its maintenance in relation to the postharvest physiology of strawberry. In A. Dale \& J. J. Luby (Eds.). The strawberry into the 21st century (pp. 145-152). Portland, Oregon, USA: Timber Press.

Kalt, W., Lawand, C., Ryan, D. A. J., McDonald, J. E., Donner, H., \& Forney, C. F. (2003). Oxygen radical absorbing capacity, anthocyanin and phenolic content of highbush blueberries (Vaccinium corymbosum L.) during ripening and storage. Journal of the American Society for Horticultural Science, 128, 917-923.

Khanizadeh, S., Ehsani-Moghaddam, B., \& Levasseur, A. (2006). Antioxidant capacity in June-bearing and day-neutral strawberry. Canadian Journal of Plant Science, 86, 1387-1390. http://dx.doi.org/10.4141/P06-113

Kovach, J., Petzoldt, R., \& Harman, G. E. (2000). Use of honey bees and bumble bees to disseminate Trichoderma harzianum 1295-22 to strawberries for Botrytis control. Biological Control, 18, 235-242. http://dx.doi.org/10.1006/bcon.2000.0839

Macheix, J.-J., Fleuriet, A., \& Billot, J. (1990). Fruit phenolics. Boca Raton, Florida, USA: CRC Press.

Martínez-Romero, D., Guillén, F., Valverde, J. M., Bailén, G., Zapata, P., Serrano, M., ... Valero, D. (2007). Influence of carvacrol on survival of Botrytis cinerea inoculated in table grapes. International Journal of Food Microbiology, 115, 144-148. http://dx.doi.org/10.1016/j.ijfoodmicro.2006.10.015

Meyers, K. J., Watkins, C. B., Pritts, M. P., \& Liu, R. H. (2003). Antioxidant and antiproliferative activities of strawberries. Journal of Agricultural and Food Chemistry, 51, 6887-6892. 
http://dx.doi.org/10.1021/jf034506n

Nicholson, R. L., \& Hammerschmidt, R. (1992). Phenolic compounds and their role in disease resistance. Annual Review of Phytopathology, 30, 369-389. http://dx.doi.org/10.1146/annurev.py.30.090192.002101

Olcott-Reid, B., \& Moore, J. N. (1995). Fruit firmness, calyx and neck ratings correlated with field fruit rot reactions of nine strawberry cultivars. Fruit Varieties Journal, 49, 14-19.

Prusky, D. (1996). Pathogen quiescence in postharvest diseases. Annual Review of Phytopathology, 34, 413-434. http://dx.doi.org/10.1146/annurev.phyto.34.1.413

Rekika, D., Khanizadeh, S., Deschênes, M., Levasseur, A., Charles, M. T., Tsao, R., \& Yang, R. (2005). Antioxidant capacity and phenolic content of selected strawberry genotypes. HortScience, 40, 1777-1781.

SAS Institute. (1989). SAS User's Guide: Statistics (6th ed.). Cary, NC.

Slinkard, K., \& Singleton, V. L. (1977). Total phenol analysis: Automation and comparison with manual methods. American Journal of Enology and Viticulture, 28, 49-55.

Sutton, J. C. (1998). Botrytis fruit rot (gray mold) and blossom blight. In J. L. Maas (Ed.). Compendium of strawberry diseases (2nd ed., pp. 28-31). St. Paul, Minnesota, USA: APS Press.

Tao, S., Zhang, S., Tsao, R., Charles, M. T., Yang, R., \& Khanizadeh, S. (2010). In vitro antifungal activity and mode of action of selected polyphenolic antioxidants on Botrytis cinerea. Archives of Phytopathology and Plant Protection, 43, 1564-1578. http://dx.doi.org/10.1080/03235400802583834

Terry, L. A., Joyce, D. C., Adikaram, N. K. B., \& Khambay, B. P .S. (2004). Preformed antifungal compounds in strawberry fruit and flower tissues. Postharvest Biology and Technology, 31, 201-212. http://dx.doi.org/10.1016/j.postharvbio.2003.08.003

Wang, Q., Tao, S., Dubé, C., Tury, E., Hao, Y.-J., Zhang, S., \& Khanizadeh, S. (2012). Postharvest Changes in the Total Phenolic Content, Antioxidant Capacity and L Phenylalanine Ammonia-Lyase Activity of Strawberries Inoculated with Botrytis Cinerea Pers. Journal of Plant Studies, 1(2), 11-18. http://dx.doi.org/10.5539/jps.v1n2p11

Wang, S. Y., Feng, R., Lu, Y., Bowman, L., \& Ding, M. (2005). Inhibitory effect on activator protein-1, nuclear factor-kappaB, and cell transformation by extracts of strawberries (Fragaria $\times$ ananassa Duch.). Journal of Agricultural and Food Chemistry, 53, 4187-4193. http://dx.doi.org/10.1021/jf0478049

Wang, S. Y., Zheng, W., \& Galletta, G. J. (2002). Cultural system affects fruit quality and antioxidant capacity in strawberries. Journal of Agricultural and Food Chemistry, 50, 6534-6542. http://dx.doi.org/10.1021/jf020614i

Xie Z., Charlebois, D., Roussel, D., Dubé, C., Charles, M. T., \& Khanizadeh, S. (2013). Agronomic characteristics and phytochemical profiles of advanced June-bearing strawberry lines for northern Canadian climate. Agricultural and Food Science, In press- http://ojs.tsv.fi/index.php/AFS/issue/current

\section{Copyrights}

Copyright for this article is retained by the author(s), with first publication rights granted to the journal.

This is an open-access article distributed under the terms and conditions of the Creative Commons Attribution license (http://creativecommons.org/licenses/by/3.0/). 